\title{
Role of Plant Growth Regulators in the Insect Pest Control: A Quick Outlook
}

\author{
Karem Ghoneim* \\ Department of Zoology and Entomology, Egypt \\ *Corresponding author: Karem Ghoneim, Professor of Entomology, Department of Zoology and Entomology, Faculty of Science, Cairo, Egypt
}

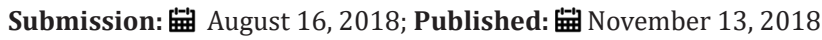

\section{Introduction}

According to Environmental Protection Agency, a plant growth regulator (PGR) is defined as "any substance or mixtures of substances intended, through physiological action, to accelerate or retard the rate of growth or maturation or otherwise alter the behavior of plants Yau [1] \& Mahajan [2]. As reported in the current literature, five principal categories of PGRs are recognized in plants: Auxins (Auxs), Gibberellins (GAs), Cytokinins (CKs), Ethylene (ET), and Abscisic acid (ABA). They are known to be produced in higher plants. In addition to these categories, two other categories appear to be active, in some cases, for regulating the plant growth: the brassinosteroids (BRs) and polyamines (POA) Naqvi [3]. Over 70 years, Aux, GAs, CKs, ABA and ET were considered as the main groups of phytohormones (for a review, see Kende \& Zeevaart [4] and Hopkins \& Hüner [5] classified the plant hormones (or PGRs) into five classes: GAs, Auxs, ET, CKs, ABA and BRs. In their review, Ogunyale et al. [6] classified PGRs in five major classes: Auxs, CKs, GAs, ET and ABA.

According to the American Society for Horticultural Science, PGRs are classified in six major classes: Auxs, GAs, CKs, ET generators, growth inhibitors and growth retardants Fishel [7]. As reported by Contreras AM \& Lopez BJ [8], the classification of PGRs into traditional six groups which have been received a great research attention all over the world are Auxs, CKs, ET, ABA, GAs and BRs.

In the last four decades, many authors Kaur \& Rup [9], Ahmad et al. [10] and Silva et al. [11] suggested that the PGRs can be used as alternative to the conventional insecticides for controlling the economically dangerous insect pests. Synthetic PGRs mimic the authentic PGRs and are marketed specifically for the purpose of stimulation or retardation of plant growth and development. They are, also, used for reduction of the insect pest infestation on crop plants Gupta et al. [12], Memon et al. [13], Ali et al. [14]and Elhamahmy et al. [15].

The available literature contains many reported works focusing on the disruptive effects of PGRs on various insect pests leading directly to death or through impairment of their reproductive potential and other physiological processes $\mathrm{Mu}$ et al. [16],
Mendonça et al. [17] and Kaur et al. [18]. Also, many PGRs had been reported to deteriorate the food metabolism in different insects, through impairment of food ingestion, digestion, absorption and assimilation, such as Gibberellic acid against Bactrocera cucurbitae Kaur \& Rup [9] Spodoptera littoralis Kaur \& Rup [9] as well as JA against Spodoptera frugiperda Gordy et al. [19].

The use of PGRs may be an effective tactic in IPM programs, since they induce the plant defenses resulting in decreased herbivore fitness Stout et al. [20], Lyon [21] and Reglinski et al. [22]. However, the available literature has been enriched with many reported works indicating the stimulatory effects of PGRs on some plants to resist herbivorous insects through various defense strategies to minimize their damage Herbert et al. [23]and Strydhorst et al. $[24,25]$.

\section{References}

1. Yau J (2011) What are Plant Growth Regulators? In: Food Safety FocusFood Safety Platform. Risk Assessment Section, Centre for Food Safety, Hong Kong, China.

2. Mahajan DP (2015) Synthesis and studies on PGR activities of heterocyclic compounds. Ph.D. Thesis, School of Chemical Sciences, North Maharashtra University, Jalgaon, India.

3. Naqvi SSM (1994) Plant hormones and stress phenomena. In: Pessarakli M (Eds.), Handbook of Plant and Crop Stress, Marcel Dekker, New York, USA, pp: 383-400.

4. Kende, H, Zeevaart JAD (1997) The five classical plant hormones. Plant Cell 9(7): 1197-1210.

5. Hopkins WG, Hüner NP (2004) Introduction to Plant Physiology. ( $3^{\text {rd }}$ edn), John Wiley and Sons, Hoboken, New Jersey, USA, pp. 560.

6. Ogunyale OG, Fawibe OO, Ajiboye AA, Agboola DA (2014) A review of plant growth substances: their forms, structures, synthesis and functions. Journal of Advanced Laboratory Research in Biology 5(4): 152168.

7. Fishel FM (2006) Plant growth regulator. Institute of Food and Agricultural Sciences, University of Florida, Document No, USA, PI-102.

8. Contreras AM, Lopez BJ (2007) Cannabinoid-like signaling and other new developmental pathways in plants. International Journal of Plant Developmental Biology 1(1): 34-41.

9. Kaur R, Rup PJ (2002) Evaluation of regulatory influence of four plant growth regulators on the reproductive potential and longevity of melon fruit fly Bactrocera cucurbitae. Phytoparasitica 30(3): 224-230. 
10. Ahmad N, Rashdi SMMS, Rajput AA (2003) Efficacy of plant growth regulators to manage the insect pests of cotton. Asian Journal of Plant Sciences 2(7): 544-547.

11. Silva MTB, Costa EC, Boss A (2003) Control of Anticarsia gemmatalis Hübner (Lepidoptera: Noctuidae) larvae with insect growth regulators. Ciência Rural 33(4): 601-605.

12. Gupta G, Yadav SR, Bhattacharya AK (2009) Influence of synthetic plant growth substances on the survivorship and developmental parameters of Spilarctia obliqua Walker (Lepidoptera: Arctiidae). Journal of Pesticide Science 82(1): 41-46.

13. Memon SA, Rustamani MA, Sahito HA, Narejo MN, Mal B, et al. (2011) Effect of agrochemicals on sucking insect pests of cotton crop. Life Science International Journal 5(3): 2280-2287.

14. Ali SS, Abro GH, Rustamani MA, Nizamani SM (2012) Effect of application of plant growth regulators on Earias vittella (Fabricius), infestation and yield components of cotton. Journal of Basic and Applied Sciences 8: 677-682.

15. Elhamahmy MAM, Mahmoud MF, Bayoumi TY (2016) The effect of applying exogenous salicylic acid on aphid infection and its influence on histo-physiological traits and thermal imaging of canola. Cercetări Agronomice în Moldova 49(2): 67-85.

16. Mu J, Uchara T, Furuno T (2003) Effect of bamboo vinegar on regulation of germination and radicle growth of seed plant. Journal of Wood Science 49(3): 262-270.

17. Mendonça JMA, Carvalho GA, Guimarães RJ, Reis PR, Rocha LCD (2006) Produtos naturais e sintéticos no controle de Leucoptera coffeella (Guérin-Mèneville \& Perrottet, 1842) (Lepidoptera: Lyonetiidae) e seus efeitos sobre a predação por vespas. Ciênc. Agrotec 30(5): 892-899.
18. Kaur N, Gillett Kaufman JL, Buss EA (2016) Effect of plant Growth Regulators on Blissus insularis (Hemiptera: Blissidae). Florida Entomologist 99(3): 557-558.

19. Gordy JW, Leonard BR, Blouin D, Davis JA, Stout M (2015) Comparative effectiveness of potential elicitors of plant resistance against Spodoptera frugiperda (J. E. Smith) (Lepidoptera: Noctuidae) in four crop plants. PLoS ONE 10(9): e0136689.

20. Stout MJ, Zehnder GW, Baur ME (2002) Potential for the use of elicitors of plant resistance in arthropod management programs. Archives of Insect Biochemistry and Physiology 51(4): 222-235.

21. Lyon GD (2014) Agents that can elicit induced resistance. In: Walters D, Newton A, Lyon G, (Eds.), Induced resistance for plant defence: A sustainable approach to crop protection. ( $2^{\text {nd }}$ edn), John Wiley and Sons, Hoboken, New Jersey, USA, pp: 11-40.

22. Reglinski T, Dann E, Deverall B (2014) Implementation of induced resistance for crop protection. In: Walters D, Newton A, Lyon G (Eds.), Induced resistance for plant defence: A sustainable approach to crop protection. $\left(2^{\text {nd }} e d n\right)$, John Wiley and Sons, Hoboken, New Jersey, USA, pp: 249-299.

23. Herbert DA, Abaye AO, Dugger P, Richer D (1999) Compensation from systematic square removal by Virginia cotton. 1999 proceedings Beltwie Cotton Conferences, Orlando, Florida USA, 2: 968-971.

24. Strydhorst S, Hall L, Perrott L (2017a) Plant growth regulators: What agronomists need to know?

25. Strydhorst S, Bowness R, Pauly D, Gill KS, Oatway L, et al. (2017b) Advanced agronomic practices in wheat, barley and pea to maximize yield and harvestability. Project final report 2014F041R. Syngenta AG. 2015 Moddus label. Syngenta UK Limited.

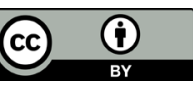

Creative Commons Attribution 4.0

International License

For possible submissions Click Here
Submit Article

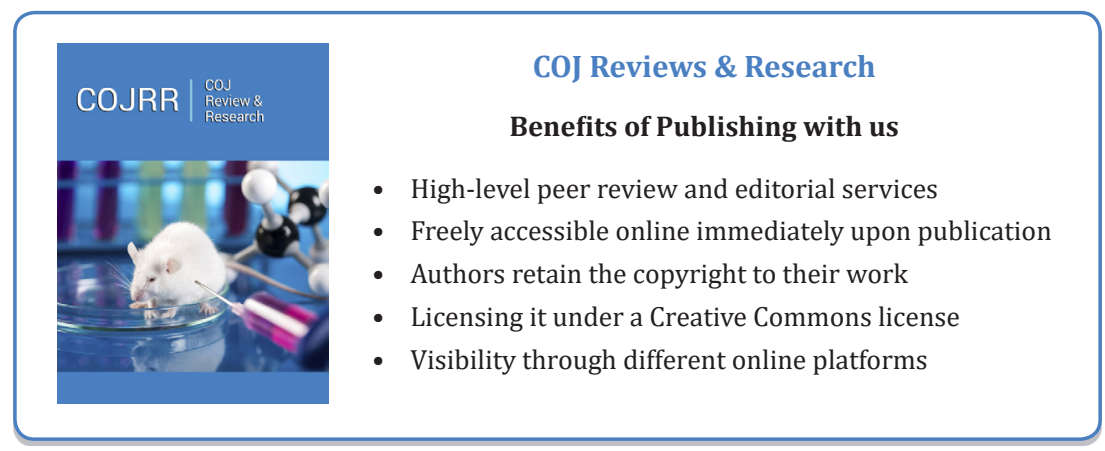

